\title{
THE ROLE OF FOOD IN DIPLOMACY: COMMUNICATING AND "WINNING HEARTS AND MINDS" THROUGH FOOD
}

"Dining is the soul of diplomacy" - Lord Palmerston

(Prime Minister of the United Kingdom 1859-1865)

Đana Luša :: Ružica Jakešević

IZVORNI ZNANSTVENI RAD / DOI: 10.20901/ms.8.16.7 / PRIMLJENO: 16.08.2017.

ABSTRACT Food as an essential ingredient of human existence, has always played an important role in interstate relations and diplomatic practice. It has been used as a medium for projecting influence, communicating one's culture, identity and messages that express friendship or enmity. Its role is becoming increasingly prominent in the public diplomacy practices of various countries, while academic accounts on gastro diplomacy, food diplomacy or culinary diplomacy within the International Relations (IR) discipline have so far been limited. The aim of this article is to introduce different aspects of this new, developing field of interdisciplinary research to the wider academic community, building on the hypothesis that food is becoming more recognized as an official soft power or public diplomacy tool. The article contains an analysis based on an initial survey conducted among the diplomats accredited in the Republic of Croatia as well as among the students of the Faculty of Political Science, University of Zagreb.

KEY WORDS

PUBLIC DIPLOMACY, FOOD DIPLOMACY, GASTRO DIPLOMACY, CULINARY DIPLOMACY, SOFT POWER, COMMUNICATION

Authors note

Đana Luša :: University of Zagreb, Faculty of Political Science, Croatia :: dana.lusa@fpzg.hr Ružica Jakešević :: University of Zagreb, Faculty of Political Science, Croatia :: ruzica.jakesevic@fpzg.hr 


\section{INTRODUCTION}

Analysing the role of food in Diplomacy or Security Studies is a relative novelty in the discipline of International Relations (IR) at the global level, as well as in Croatian political science, the exception being found in the writings of a few distinguished authors reflecting on their diplomatic careers or focusing on diplomatic protocol and ceremony (Bišćević, 2013; Nick, 1997; Mikolić, 2002). However, "food as a part of what is referred to as 'soft-power' or a public diplomacy tool has been recognized in the diplomatic practices of different countries since ancient times" (Zhang, 2015: 570). In Croatia, it was mostly used during the early years of statehood in lobbying and communicating the political message to the outside world, and especially in diplomatic circles to promote the newly established country. While terms such as food diplomacy, gastro diplomacy and culinary diplomacy are very rare in the political and academic discourse in Croatia, there are multiple examples from diplomatic history and contemporary diplomatic practice, which provide us with enough incentives for assessing the role food can play in interstate relations, public diplomacy, diplomatic communication and political communication in general." According to Costas Constantinou "if we are to understand gastronomy simply as a natural or personal activity, or only as a socialising device, we run the risk of leaving unexamined the political implications of it" (1996: 126).

Therefore, the aim of this article is to introduce different aspects of this new developing field of interdisciplinary research to the wider academic community, as well as to provide the basis for initiating empirical research of this topic in Croatia. It encompasses an analysis of several historical and recent examples of the use of food in interstate relations, the results of a preliminary study of the role of food in diplomatic activities in Croatia, as well as of the public perception of gastro diplomacy as a public diplomacy tool. We build our arguments on the hypothesis that food is becoming more recognized as an official soft power and public diplomacy tool, presenting a means of communication (intended or unintended) in diplomacy and of strengthening national identity.

\section{DEFINITION OF KEY CONCEPTS}

There are several terms, which will be explained in this article, in order to highlight various roles that food can play in different forms of interaction and communication associated with formal and informal diplomatic activities. Despite the "multiplication" of concepts, some authors imply that one needs to be cautious when designating a particular activity as a new form of diplomacy - including all types of diplomacy involving food since these only represent various tools at the disposal "of broader diplomatic strategies" (Riordan, 2017: 1). However, the power of food has been recognized by an increasing number of countries, while several of them are described as great, gastro diplomacy

\footnotetext{
${ }^{1}$ Such examples include the so-called "food wars" that have recently taken place between Croatia and its neighbours in the process of, and following the accession to the EU. These are mostly related to the ownership of different sorts of food and drinks, or the labels for such items, whereby the issues of originality, belonging and identity gained political significance, and as such were highly politicised. The latest case is the initiative coming from the Visegrád group countries "who accuse multinational food companies of selling them inferior quality products compared to richer European nations" (Bertrand, 2017).
} 
nations - Japan, Thailand, the Nordic countries (Denmark, Norway, Sweden), Malaysia, Peru, South Korea, Taiwan and Australia (USC CPD, 2015).

\section{Soft power and public diplomacy}

The most appropriate theoretical concept for explaining the connection between food, politics and diplomacy is the concept of soft power, which is attributed to influential IR theorist, Joseph Nye (1990). As an analytical tool, the concept of soft power serves as the antipode to the widely present concept of hard power, based on military capabilities and coercion, which dominate the Realist theory of International Relations. Soft power is usually described as the ability to project influence to achieve desired outcomes (normally in the field of politics), using means other than military strength and coercion. The concept has gained prominence in the post-Cold War period, when Nye (1990: 164-166) argued that the nature of power and security in world politics has changed, whereby the central question for the great powers (but not just for them) is how to achieve influence in a complex international political environment which is increasingly interdependent. His answer lies in the following explanation:

If a state can make its power seem legitimate in the eyes of others, it will encounter less resistance to its wishes. If its culture and ideology are attractive, others will more willingly follow. If it can establish international norms consistent with its society, it is less likely to have to change. If it can support institutions that make other states wish to channel or limit their activities in ways the dominant state prefers, it may be spared the costly exercise of coercive or hard power. (Nye, 1990: 167)

The revival of the concept happened in the post-September 11, 2001 world, and has gained additional prominence after Nye's book Soft Power: The Means to Success in World Politics was released in 2004. In other words, the soft power concept encompasses a plethora of mainly non-tangible factors, instruments and means, such as attractiveness, influence, image or ideology, whose final aim is the creation of the capability of appeal, attraction, and non-military persuasion. It is often described as "winning the hearts and minds" (ASEF, 2016: 70) of a targeted population to make them understand, support, and follow one's policies, goals, cultural traditions or way of life. In our case, the connection between public diplomacy and food can best be described by using the words of Paul Rockower, who states that "gastro diplomacy is the act of winning hearts and minds through stomachs." (2012: 235)

Public diplomacy and soft power are strongly interlinked. Components of soft power, such as "culture, values and policies" (Nye, 2008: 94), serve as tools within the practice of public diplomacy, through which a country communicates messages to a specific or general population in order to achieve desired outcomes. On the other hand, this connection between the two is also described the other way around, whereby public diplomacy is considered to be "one of soft power's key instruments" (Melissen, 2005: 4). The crucial moment in this case is the power of creating attractiveness, which then serves as an incentive to other actors, either to create stronger ties with certain actors or to absorb its values, ideologies or even lifestyle. Here, national cuisine can present a strong medium for the purposes of public diplomacy. However, academic accounts of the role of food in public diplomacy can still be considered rare - for example, the Routledge 
Handbook of Public Diplomacy (Snow and Taylor, 2009), which encompasses a set of 29 chapters, does not provide any analyses of food as a possible instrument in the wider diplomatic practice, in the manner this article aims to provide.

\section{Culinary and gastro diplomacy}

Culinary diplomacy is a distinctive form of communication through food, and is occasionally used as a synonym for gastro diplomacy, although some authors make a distinction between the two concepts. In terms of activities, it can encompass not only consummation in the sense of tasting food of a specific origin, but also in the 'rituals' or practices of preparation, serving and eating, presenting a kind of performative act. Another definition is that offered by Sam Chapple-Sokol, who defines culinary diplomacy as the "use of food or a cuisine as a tool to create a cross-cultural understanding in the hopes of improving interactions and cooperation." (Chapple-Sokol, 2013: 161)

As previously noted, although often used by some authors as a synonym for gastro diplomacy (Spence, 2016), others such as Paul Rockower (2012) distinguish between the two terms. This distinction is best explained through the lens of the targeted audience or the level of actors involved in communication. In the case of culinary diplomacy, the scope of the audience is narrower and involves the official and formal diplomatic governmentto-government communication; while, on the other hand, gastro diplomacy is intended to encompass a wider range of 'users' and aims to deliver a specific message to the larger populations of other countries through food (Zhang, 2015: 569). According to Rockower "gastro diplomacy is to culinary diplomacy what public diplomacy is to diplomacy. It is the act of winning hearts and minds through stomachs" (2012: 235-237), a form of a food culture exchange, a promotional tool and a way to influence the public at the cultural level. It is a tool for mutual understanding.

Another related term, yet different in scope, is food diplomacy. This type of public diplomacy is strongly interlinked with the global efforts to reduce world hunger, and it is used as a developmental tool by intergovernmental organisations, civil society organisations as well as states themselves. Its primary and most direct objects are the recipients of food aid in parts of the world affected by conflicts, poverty and resource scarcity, as well as natural and man-made disasters. It can serve as a medium for sending political messages to designated populations, but also to the wider global community. Consequently, food diplomacy in its most common form of food aid has been used by many states as a very tangible symbol, which helps in the creation of a positive image in the international community. A positive image contributes to attractiveness, which is one of the central features of soft power. This term seems more technical and 'tangible' then the two previously defined concepts, yet at the same time, it is also much narrower. It is defined as "using food aid as a tool of public outreach to reduce global hunger [which is] a developmental tool as well as diplomatic tool" (Chapple-Sokol, 2013: 162).

In the following sections, we present the results of the initial research on the use of gastro diplomacy by diplomats in Croatia as well as the perception of the issue by the students of the Faculty of Political Science of the University of Zagreb. Various examples of 
the role of food in the history of diplomacy, its manifestation as a tool in public diplomacy that strengthens national identity and creates national brands are also elaborated. The use of food as a form of communication is particularly reflected upon. According to Roland Barthes (2008: 29) "food is a system of communication, a body of images, a protocol of usages, situations and behaviour."

\section{FOOD IN THE HISTORY OF DIPLOMACY}

There has always been a strong connection between food and diplomacy. For more than 12,000 years humans have been sharing food (Spence, 2016: 1). To put it more generally, "there has never been a great event, not even conspiracies, which was not conceived, worked out and organised over a meal" (Steel, 2008: 220). Social entertainment has been considered as a necessary tool of diplomacy, which is seen "from the habit of ambassadors always to take their own cook to avoid or instigate poisoning." (Constantinou, 1996: 125)²

Jean Anthelme Brillat-Savarin, a French lawyer, politician and deputy to the National Constituent Assembly, mostly famous as a French gastronome, in his book The Physiology of Taste presented several aphorisms that demonstrate the importance of food in everyday life, as well as in the political sphere:

"The destiny of nations depends on the manner in which they are fed"; "Tell me what kind of food you eat and I will tell you what kind of man you are"; "The discovery of a new dish confers more happiness on humanity, than the discovery of a new star." (Brillat-Savarin, 2009: 3)

During Archaic Greece (630-480 B.C.), the Greeks especially enjoyed the symposium as an ideal form of entertainment and drinking, which followed the main meal, and was reserved for men. After the Macedonian conquest in the $4^{\text {th }}$ century B.C., the symposium became "a little bit more" complex and meaningful. Alexander the Great "spread Greek culture throughout his empire, stretching from the Adriatic in the west to the Ganges in the east." (Weiss Adamson and Segan, 2008: 7-17) The welcoming of foreign ambassadors involved a gastronomic practice, as well as the welcoming return of one's own ambassadors. After the end of their mission, Athenian ambassadors were always given an invitation to a public dinner. Namely, the importance of shared meals "laid in the fact that those who shared in food and drinks, also shared in thought and diplomatic conduct." (Constantinou, 1996: 130) Even the first corps diplomatique was established because of this practice of sharing common meals among ambassadors. The Greeks "managed to achieve most worthy of gastronomic ideals: good taste without excess, attention to health, balance and moderation - a culinary culture as well conceived as their political forms" (Albala, 2011: 17). They were accepted as the ideal roots of Western civilisation.

At the earliest ages, societies were built upon systems of food production and distribution, with food serving as a medium of payment. After the emergence of different

\footnotetext{
2 The importance of having your own cook was also highlighted by poison being a murder weapon in the courts of the GrecoRoman world (the deaths of Alexander the Great and Augustus Caesar were rumoured to have been caused by poison). The fear from poisoning even led to the development of a food-taster or praegustatores (Johnston, 2013: 1-3).
} 
civilisations "food helped to connect them together." (Standage, 2009: 13) Even the New World was discovered because of the Europeans' strive to overcome Arab merchants' spice monopoly and create new food-trade routes. The appeal of spices gave Alexandrian and later Roman sailors an incentive to access the India's west coast bypassing Arabia and leading to Europe. It resulted with the mightiest empires in Euroasia being connected by trade routes. The Muslim world provided "a fertile environment in which trade could prosper" (Ibid.: 76-80) with some $80 \%$ of trade with the East in the $15^{\text {th }}$ century being in its hands. This resulted with Europeans trying to find alternative routes to the East. And what is most important - spices (food) helped "for Columbus to go westward, de Gama eastwards, to establish new sea routes" and "inspired the first circumnavigation of the earth" (Ibid.: 96). However, as spices became more affordable in the $17^{\text {th }}$ century, they ceased to be an important tool in the diplomacy of that time.

The control of food supplies was often used as an effective weapon in wars. This is illustrated by Publius Flavius Vegetius Renatus (Milner, 1996: xxvi), who noted that "armies are more often destroyed by starvation than battles, and hunger is more savage than the sword". Food supplies and logistics played a crucial role in the conquests of Alexander the Great, during the Second Punic War between Rome and Carthage, and then in the American Revolutionary War, as well as in a series of Napoleon's victories. After the battle in Austerlitz, Napoleon concluded that "an army marches on its stomach" (Standage, 2009: 144).

Gastro diplomacy is mostly connected with the emergence of modern diplomacy rooted in Cardinal Richelieu's creation of the new system of permanent embassies. Louis XIV, or the Sun King, used ceremony to show his power, as well as to distance himself from the people. Everything became ceremonial from the time the king woke up until he went to bed. Culinary extravagance was especially characteristic for the French monarch, with 324 people employed in the kitchens of Versailles (Lair, 2011: 146). Utilising ceremony made the French court extremely influential among the European courts. The Ancient Regime had access to "haute cuisine", extravagance and the best chefs, who opened their own restaurants following the French Revolution, to serve the new elite of the $19^{\text {th }}$ century - the bourgeoisie. Aside from being the centre of politics and culture, Paris soon became the gastronomic capital of Europe.

An interesting example of gastro diplomacy comes from the Ottoman envoy to the king of France in the $18^{\text {th }}$ century, whose numerous kitchen staff even included a person who made Turkish coffee (Constantinou, 1996: 125). Gastronomy was also very significant in the diplomatic communication between the Ottoman Empire and the Europeans. Besides this importance, other gastronomical differences played their role in exposing the elites of the two countries to one another's culture. The Ottomans, used to small and private meals without dining rooms, with women eating separately, eating in silence and not using napkins, forks or knives, were shocked by European practices. This marked "gastronomic exoticism of Eastern versus Western eating habits." (Ibid.: 137)

The impact of the French Revolution brought forth the end of absolutist regimes in Western Europe, which reflected in the monarchs no longer claiming superiority to 
"everything and everyone as God's representatives on earth" (De Vooght, 2011: 171). Unlike in the seventeenth and eighteenth centuries, when a group of courtiers were assembled around the absolute monarch, the $19^{\text {th }}$ century court dinners convened all sorts of people on an almost daily basis. This shows food helping kings and queens seem more ordinary (lbid.).

A diplomat always wants to impress a guest with food from his or her country, but also shows respect by serving food from the guest's home country. For example, the hot dog has played a role in American foreign relations since June 1939, and a picnic organised by President Franklin D. Roosevelt for the king and queen of England. One of the main topics was American support for England in the forthcoming war. However, The New York Times shared the story on the front page with the title "King tries hot dog and asks for more" (Barry, 2009). This shows how important food is in diplomacy. It was ascertained that the king enjoyed a favourite American snack and even drank some beer, sending a message of friendship and understanding (Ibid.).

In the $20^{\text {th }}$ century food took on a role "as an ideological weapon during the Cold War" (Standage, 2009: 156). The most known example of food being used as a weapon against the Communists, occurred during the Berlin blockade (from June 1948 to September 1949), when the Soviets blocked access to West Berlin by road, rail and canals. The Allies reacted by organising the Berlin Airlift to carry supplies to the people in West Berlin. A similar use of food was also demonstrated on a poster from 1949 created by the United States to bring attention to the Airlift, in which a girl is holding up a glass of milk, with more floating from an aircraft. The headline stated "Milk... new weapon of democracy" (Ibid.).

The next example dates from the fall of 1959, when the Soviet Premier, Nikita Khrushchev, tasted his first American hot dog during a visit to the United States, after supposedly "the first bite had to wait until security agents waved a Geiger counter over the food." (Barry, 2009) Asked to comment on the hot dog he stated: "Ok, excellent, wonderful, but added that it wasn't enough." (WNYC.org, 2014) This shows the Cold War being fought on the "food front". The role of food in diplomacy is also registered in a letter by President Park Chung Hee of South Korea, telling President Lyndon Johnson that his soldiers fighting in Vietnam were miserable because of a shortage of kimchi, a traditional Korean national dish (Sang-Hun, 2008). After the Americans financed the delivery of kimchi, William Bundy, Assistant Secretary of State, supposedly concluded that the "Vietcong would never be able to hold the Koreans once kimchi arrived" (Ibid.). Sometimes state visits can be arranged around informal meals, which further diplomatic intimacy and "results in more positive social interactions between those who dine together." (Spence, 2016: 2). For example, in 2001 President George W. Bush invited Russian President Vladimir Putin to his ranch in Texas to discuss the situation in Afghanistan, as well as the AntiMissile Treaty. On that occasion, a barbecue dinner was organised (Sanger, 2001). Chinese President Jiang Zemin was also received at Bush's ranch in Crawford, during his last visit to the United States, with barbecue serving as a message of more friendly relations. As home hospitality was previously granted to President Putin, Prime Minister Tony Blair and Crown 
Prince Abdullah of Saudi Arabia, it was concluded that "Mr. Jiang is receiving the highest level of reception." (Eckholm, 2002)

The nature of food served at diplomatic receptions and summits is very important for decision-making. For example, the sweet taste influences a friendlier attitude, while the bitter taste enhances hostility (Sagioglou and Greitemayer, 2014: 1589-1597). According to the former French Prime minister Jean-Pierre Raffarin, "the table is the place where power has influence, where tensions are eased and where relations are built." (cf. Watfa and Pallister, 2017) The next section discusses the role of "food wars", manifested as embargoes and coercion in interstate relations, as well as their use as a political communication tool in intrastate relations.

\section{'FOOD WARS' AND THE USE OF FOOD AS A MEANS OF DIPLOMATIC COMMUNICATION}

The political dimension of food has so far rarely been mentioned in IR analyses, although it is a very potent source of power. As a matter of fact, it can be said that food is a deeply political category. One of the many purposes and functions of food is the one which is linked to interstate relations. Due to its vital role in the survival of the very base of any society - the population itself -food can serve as a very powerful tool of influence on certain actors' behaviour. In this context, it can be used as one element of coercive diplomacy, whereby embargoes (among other measures) are applied prior to the use of hard power, in order to alter intentions, plans and policies or prevent actions by different actors. The application of embargoes and blockades (the most recent example being Qatar) ${ }^{3}$, food programs and politicisation (or even securitisation) of food shows that besides its predominant association with soft power and public diplomacy, it can serve as a means of hard power as well (Reynolds, 2010). In diplomatic discourse and practice, food can represent a means of communication, since according to Zhang, "food and its symbolic representation can be used to communicate ideas, values, identities, and attitudes." (2015: 568) Not only can it be used, but it has been used constantly in interstate communication, formal and informal encounters between political leaders, in building national image or in peace-building.

The fact that 'belonging' is very important when it comes to the role of food in shaping national identity is exemplified in numerous instances of the so-called "food wars": Israeli/ Lebanese over hummus (Ariel, 2012), Israeli/Palestinian over falafel (Raviv, 2003), or Greek/ Turkish over baklava (Bardenstein, 2010; Georges, 1984). Just how important is it to legally protect authenticity on the European market is emphasised by EU legislation allowing member states to protect their traditional products in line with one of three categories: "Protected Designation of Origin (PDO)", "Protected Geographical Indication (PGI)" and

\footnotetext{
${ }^{3}$ In June 2017 Saudi Arabia, Bahrain, Egypt and United Arab Emirates, followed by a number of other countries, cut off their diplomatic and trade ties with Qatar, thus protesting against its relations with Iran and accusing the country of supporting terrorism. One of the consequences of Saudi Arabia closing its borders with Qatar was the reduction in food supplies, whereby food (in)security gained prominence as one of the most direct consequences of the political crisis felt by Qatari citizens (BBC, 2017).
} 
"Traditional Specialty Guaranteed (TSG)" (European Commission, 2017). To obtain a protection label for their products under one of the mentioned categories, EU member states also engage in 'food wars'. Besides the mentioned examples that are very well known globally, several disputes between Croatia and some neighbouring countries (Italy and Slovenia) should also be noted, regarding the use of labels for certain types of food or drink, occurring during the EU accession process. These include Croatian-Slovenian disputes over the "Kranjska kobasica" sausage (Carniolan sausage) or the "Teran" wine, which have caused frictions in interstate relations, while economic, but also identity issues were highlighted by both sides (Šišović, 2017).

The use of food in interstate relations can take many forms, formal or less formal, whose outcome might yield intended, but also unintended consequences. Food can thus become a medium for sending political messages and usually involves a lot of symbolism, which is supposed to reflect the very nature of the intended message, but also the image of the country. Yet, a sweet thing like chocolate recently managed to make bilateral relations between Croatia and Serbia, as well as Slovenia, taste bitter. In early December 2016 Croatian President Kolinda Grabar-Kitarović visited Dubrovnik on the occasion of Dubrovnik Defenders' Day. Besides participating in the formal celebrations and meetings, the president also dedicated some time in her protocol for visiting local children, to whom she gave presents. When the presents were opened, it was discovered that among a variety of candies, there was also one chocolate bar produced by Pionir, a Serbian company. Some parents expressed their discontent, setting off a series of reactions, some of which caused tensions in interstate relations. The Croatian President apologised for giving the children non-Croatian chocolate, and promised to "apologise to parents and send them Croatian products instead" (Hina, Jutarnji.hr, 2016). As one can imagine, this apology was deemed as a bad move by many domestically, but also in the Serbian public and among Serbian officials. This "Chocolate affair" revealed how food has the power of sending unintended, unwanted messages both to domestic, as well as the international audience, and thus can cause friction in inter-state relations.

By the end of the same month, another "Chocolate affair", but this time in CroatianSlovenian relations occurred. As it was 'the most festive time of the year', the Croatian embassy in Ljubljana decided to send a convenient gift to the employees of the Slovenian Ministry of foreign affairs - a box of chocolates labeled 'Greetings from Croatia', produced by the Croatian company Kraš, and widely present on the Croatian market. What does the box look like? It's a blue square-shaped box containing a relief map of Croatia. Why is the appearance of the package important? Because Slovenian officials deemed it a provocation, since the map included part of the Adriatic Sea (Piran Bay), which, at that time had been (and still is) a subject of a bilateral border dispute between two countries. The gift was returned to the Croatian embassy in bags which had a printed sign 'I feel sLOVEnia' (Pavlić, 2016).

Both cases were widely considered as pieces of unsuccessful communication, provoking interstate tensions, which could have caused serious economic consequences as well. They are also far from being lone examples. 
Except from its use in interstate communication, food also represents a very common tool in intrastate political communication and campaigns (Spence, 2016). During election campaigns politicians are judged on a daily basis, which includes their eating habits. UKIP's ${ }^{4}$ leader Nigel Farage is a great example, drinking (mostly a pint of beer) during the Brexit campaign in the UK to present himself as normal and ordinary and to connect with the common man (Stanley, 2015 in Spence, 2016). Charles Spence even raised a question whether this kind of campaigning - using alcohol to convey a message - points to a new form of diplomacy: an "alco-diplomacy" (2016: 6). Donald Trump has also often taken the opportunity to win votes by eating fast food. However, he was criticised "for eating everyman's food on board of a private jet" (Zaru, 2016).

The following section discusses gastro nationalism, national identity, and branding, which have been developed by countries in their campaigns to familiarise the wider international audience with their national cuisine.

\section{GASTRO NATIONALISM - COMMUNICATING IDENTITY THROUGH FOOD}

In the era of globalisation, the line between national and international, local and global, domestic and foreign is increasingly blurred. The growing intensity of different forms of communication and cultural exchange, the flow of people and goods create a state of complex interconnectedness between numerous subjects in the international environment. In such circumstances, issues of national identity and belonging appear as categories that are hard to preserve and protect from various influences and transformation.

As one component of national identity, culinary identity and tradition, local foods and national dishes are also exposed to the influence of such global trends, whereby the need for their protection seems ever more important. Although not exclusively connected to globalisation, the phenomenon of gastro nationalism appears as a persistent effort to preserve a claim over specific types of food or drinks, specificity of one nations' flavours and tastes or culinary experiences, offering them at the same time, under that national etiquette, to the global market. In other words, according to the findings of Atsuko Ichijo and Ronald Ranta, food is often regarded as 'national', thus bearing clear political connotations, while at the same time "the relationship between food and national identity has not been systematically addressed" (Ichijo and Ranta, 2016: 1). According to ChappleSokol gastro nationalism serves a nation "to invoke the power of its cuisine as the tool of the national brand, so when foreigners take a bite of food, they recognise its belonging to the country of origins, and strengthen their association with that country" (2013: 170). Therefore, efforts by different countries to attach a "national etiquette" to a certain type of food (or drink), the technique of preparing and serving food is closely connected to what is increasingly recognized as "food nationalism". With time, nations have become very innovative in promoting their food.

\footnotetext{
$\overline{4}$ The UK Independence Party
} 
Most modern states defined their national cuisines simultaneously with the birth of movements for independence. Often, they just highlighted something that already existed, but some states engaged themselves in creating national cuisines from fragments (Higman, 2012: 163). Once a national cuisine is established, a country can use it as a nation's brand. Nation-branding is a concept that "relies on marketing and nationalism to create a strong image and to build a good reputation of a country." (Anholt, 2007 cf. ChappleSokol, 2013: 169)

The French saw the globalisation process as an assault to their culture, with strong support from the state, which searched to regulate food production and distribution, as well as to monitor authenticity and quality. They achieved a great success with the "gastronomic meal of the French" winning a place on UNESCO's list of world-class Intangible Cultural Heritage (Higman, 2012: 172). President Nicolas Sarkozy started the bid by saying: "We have the best gastronomy in the world - at least from our point of view." (Sciolino, 2008) Their aim was the "global promotion and protection of the finest cultural expressions around the world" (Ibid.). This incentive was to protect "a great source of national pride" (Ibid.), which is very much active also in light of recent immigration waves to Europe. From the perspective of the Republic of Croatia, one important moment in recognising its culinary identity, which is by virtue of geography shared among several countries, ${ }^{5}$ happened when UNESCO inscribed the 'Mediterranean diet' on its Representative List of the Intangible Cultural Heritage of Humanity in 2013. Describing the Mediterranean diet as a "set of skills, knowledge, rituals, symbols and traditions (...)" UNESCO concluded that "eating together is the foundation of the cultural identity and continuity of communities throughout the Mediterranean (...) and a moment of social exchange and communication, an affirmation and renewal of family, group or community identity" (UNESCO, 2013).

Several countries have started programs to promote their national cuisines and Japan has launched a global sushi campaign, South Korea promoted kimchi, Taiwan developed a Gourmet Taiwan plan, Peru launched a Cocina Peruana campaign, the Malaysian government launched the Malaysia Kitchen for the World campaign, the Singapore government created Singapore Encore, the US government has established the Diplomatic Culinary Partnership Initiative, and China started a Chinese food festival at UN headquarters (for more see Zhang, 2015: 569).

The concept of a distinctive Japanese national cuisine or "Washoku" (traditional Japanese cuisine that highlights the ingredients, preparation and a way of eating) was invented "in response to the increasing influence of foreign cuisines" (Qian Ng, 2015) in $19^{\text {th }}$ century. The reason for this later date is the fact that Japan was more "a borrower than an originator in the culinary field" (Ibid.). The development of Japanese cuisine involved "the trinity of cooking styles" (Ibid.) dependent on Chinese, Western and Japanese models. With the naturalization of new additions to their cuisine, they managed to preserve the notion of a national cuisine. In 2013 "Washoku was recognized by UNESCO as an UN intangible cultural heritage asset" (Ibid.).

\footnotetext{
$\overline{{ }^{5} \text { Cyprus, }}$ Croatia, Spain, Greece, Italy, Morocco and Portugal.
} 
Because of the strong influence by its neighbours, Thailand's government started the "Global Thai program" (Qian Ng, 2015). The aim of the campaign was "not only to introduce delicious spicy Thai food to thousands of new tummies, open new restaurants and persuade more people to visit Thailand, but also to help deepen relations with other countries" (The Economist, 2002). The second program, labeled "Thailand: Kitchen of the World", attempted to educate the audience on the history of Thai cuisine. All these efforts present a "multilayered nation-branding" (Rockower, 2012: 238).

Inspired by Thailand's program, the Korean government announced its own campaign called "Korean Cuisine to the World" in 2009, with the aim of "making Korean food one of the five most popular ethnic cuisines in the world" (Chapple-Sokol, 2013: 175). It included increasing the number of Korean restaurants worldwide, as well as cooking programs at international cooking schools and the standardisation of Korean cooking methods. The former first lady Kim Yoon-ok has been actively engaged in raising global awareness on Korean cuisine. According to Kim Yoon-ok "Cuisine not only reflects the level of culture of a nation, but also represents its brand value", which makes the globalisation of Korean food a "crucial job for the government" (Yoon-ok, 2010 cf. Hyun-kyung, 2010).

Thus, the more attention attributed to a country's cuisine, the stronger the understanding of its culture. According to Rockower, the maxim for countries conducting gastro diplomacy is "To taste is to love us" (2012: 247).

\section{RESEARCH FRAMEWORK}

In order to find out whether food is recognized as a soft power tool in everyday diplomatic practice, we conducted a preliminary quantitative research based on two e-questionnaires: one among diplomats accredited to the Republic of Croatia and the other among students of the Faculty of Political Science of the University of Zagreb. Since this was an initial research on gastro diplomacy as the developing field of diplomacy, we used the e-questionnaires to reach as many respondents as possible, and subsequent data, in two selected groups.

Although this preliminary research is very narrow in terms of respondents included and questions being asked, the responses we received gave us enough input to be able to make some conclusions regarding different uses of food in diplomatic practice, as well as an incentive for future, more comprehensive research focused on different gastro diplomacy strategies. We used a combination of open-ended questions, which "allowed the respondents to express an opinion" and close-ended questions, "which although limiting the respondents to a set of alternatives being offered, helped us receive initial information needed to evaluate different forms of using food in public diplomacy" (Foddy, 1993: 127). According to Vesna Lamza Posavec (2011: 17-39), open-ended questions are particularly useful as the additional explanation to the closed-ended questions and in this preliminary type of research when one does not possess enough knowledge on the subject matter. 


\section{E-questionnaire with diplomatic personnel accredited in Croatia}

The first e-questionnaire was composed of 13 closed-ended and 8 open-ended questions. Open-ended questions mostly offered single choices, except one regarding the person(s) in charge of food policy in a particular embassy. The combination of open and closed-ended questions enabled us to find out, first, whether diplomatic missions in Croatia use food as a soft power tool; second, how it is used in everyday diplomatic practice; and third, whether gastro diplomacy presents an integral part of their public diplomacy.

In conducting this survey, we decided to use the network already established through the cooperation of academic community (Faculty of Political Science, Zagreb) and embassies accredited to Zagreb. This cooperation enables students attending courses related to diplomacy to visit various embassies throughout semester and find out more on diplomatic practice via lectures, presentations and roundtables, but it also extends to the visits and lectures of ambassadors at the Faculty. The network provided us with the two relevant groups of respondents: diplomatic and student communities.

The first questionnaire was distributed by email containing a direct link to the on-line form in the period between 1 June and 1 August 2017 among 25 diplomatic missions (out of approximately 120 diplomatic missions based in Croatia or covering Croatia from third countries), which resulted in 15 responses received (Belgium, Bosnia and Herzegovina, Brazil (two responses), Bulgaria, Canada (two responses), Japan, Spain, Slovenia, Turkey (two responses), the US, United Kingdom (two responses). This part of the survey encompassed a non-probabilistic intended sample, which was the most appropriate considering the type and goals of the research.

\section{E-questionnaire among students of the Faculty of Political Science}

After receiving input from diplomats accredited to Croatia, we conducted the second phase of the preliminary research, building on the findings of the first phase. For that purpose, we used a Google online questionnaire as the main data collection tool, which was distributed to three generations of students who attended the course of Contemporary Diplomacy (academic years 2014/2015, 2015/2016 and 2016/2017, a total of 308 students) and to one generation of students who attended the course History of Diplomacy (academic year 2016/2017, a total of 48 students). The questionnaire was composed of 25 questions out of which seven were open-ended and was distributed in the period between 3 and 15 November 2017 through the e-learning platform (Merlin) and the intranet of the Faculty of Political Science. Again, the probabilistic occasional sample was used, resulting with 95 responses. The aim of this part of the research was to detect the familiarity of students with the terms used in the context of gastro diplomacy, perception of certain countries based on food experiences, the role of food as a public diplomacy tool and means of communication, as well as the extent to which food is used by Croatia as a public diplomacy tool. 
In both cases, the level of anonymity was guaranteed to the respondents. In the case of diplomatic missions, respondents could be identified with specific country, but not personally. Within the student sample, researchers were familiar only with the groups of students which were encompassed without any specific references to their individual identities.

\section{RESEARCH FINDINGS - THE USE OF FOOD IN DIPLOMATIC PRACTICE}

Among the surveyed diplomatic representatives, 13 respondents find food to be important for the diplomacy of their county, while all of them use food as a tool of promotion. However, 11 respondents recognise they do not implement a gastro diplomacy strategy on a daily basis, with just 4 embassies receiving instructions from their ministries of foreign affairs regarding gastro diplomacy. The lack of a consistent gastro diplomacy strategy is also evident, with more than half of respondents (8) believing their country is not investing enough in it. Only 6 embassies serve food at every single event they organise, with the ambassador being the person in charge of the food choices (12), followed by diplomatic staff (3). The majority of embassies (9) mainly serve food from their own country (i.e. feijoada, Pao de queio, coxinha, potica, baklava, sushi, fish and chips, curry, etc.). Regarding the questions addressing the different uses of gastro diplomacy, we detected that 6 respondents consider food something that can play a role in reconciliation in international relations, while only one respondent thinks it can serve as means of radicalisation.

These results indicate a strong role for food in the public diplomacy practices of embassies accredited to the Republic of Croatia, however, a comprehensive gastro diplomacy strategic planning directed_from the government is missing. Furthermore, embassies are using their national food and cuisine to promote their country and to communicate basic ideas they want their target audience to remember.

The first open-ended question in the second questionnaire was supposed to detect whether students are familiar with the term gastro diplomacy. In their responses they define it as: the diplomacy of food, spreading the national culture through national cuisine, foreign relations based on cuisine, a type of cultural and public diplomacy for a country's promotion by using national specialties and autochthonous dishes, as well as different techniques of their preparation, international cooperation at the table, using food to achieve certain national goals, a foreign policy instrument, sending message through food, diplomacy through stomachs, the promotion of national identity and cultural exchange with political motives. Another set of questions was aimed at detecting whether food influenced respondents' perception of a certain country, whereby 71 responded positively, while the consummation of a certain food managed to change one's already formed perception of a particular country among 43 respondents ( 29 for better, 14 for worse). Additionally, the consummation of a certain food encouraged 36 respondents to consider visiting a country of its origin, 19 were encouraged to learn more about the country, 11 
to share information about the country with other people, while 16 were motivated to buy other products originating from that country. Italy is overwhelmingly recognized as a country using gastro diplomacy as a public diplomacy tool (59), while other countries such as Mexico (8), China (5), Japan (5), France (4) and India (4) are recognized as such to a far less extent. Similarly, Italy (49), China (15), Mexico (10), Japan (7), Thailand (5) and India (5) are perceived as countries which use food as a soft power tool.

In the next part of the questionnaire, we wanted to find out what kind of role students attribute to food as a public diplomacy tool: to what extent do they perceive it as a means of communication (sending intended or unintended messages), and to what extent as a means of strengthening the national identity. Among the received responses, 39 think that food can be used as a means of intended diplomatic communication (Graph 1). Particularly interesting are answers regarding the messages which Croatia could transmit through gastro diplomacy: an inviting, cooperative, friendly, eco-friendly and touristic country with rich historic heritage. On the other hand, in terms of potential negative outcomes of unintended messages that can be sent through food, $38.5 \%$ of respondents think that food can cause radicalisation or a deterioration of interstate relations, while $50 \%$ do not share that opinion. The follow-up question regarding the potential of food in generating provocations in diplomatic relations, shows that strong majority of respondents $(63.2 \%)$ think that food can serve such purpose.

\section{Do you think food can be used as a means of intendede diplomatic communication?}

Yes

No

Don't know

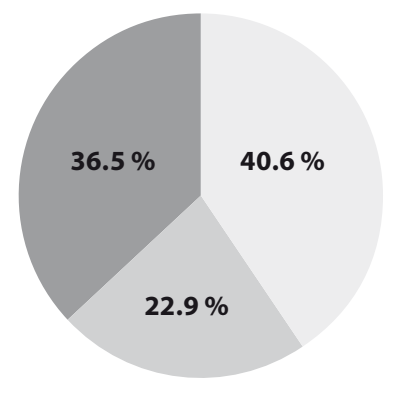

A Graph 1.

Food as a means of diplomatic communication, $\mathrm{N}=95$

Graph 2 visualises the responses to the question "Do you think that food can serve as a means of strengthening national identity?" Collected data lead to the conclusion that a predominant majority (81.3\%) of 95 respondents recognise the potential of food in creating a distinctive brand and in a countries' efforts to improve their national image. 
Do you think the food can serve as a means of strenghtening the national identity?

Yes

No

Don't know

$81.3 \%$

A Graph 2.

The role of food in strengthening the national identity, $\mathrm{N}=95$

The third group of questions was aimed at detecting students' perception of the extent to which Croatia uses food as a public diplomacy tool. Although it is not surprising that a majority of respondents recognize tourism (68.8\%) and sports (25\%) as the most distinctive features of Croatian public diplomacy, the fact that only two students see gastronomy as a predominant public diplomacy tool can serve as an indicator that the use of gastro diplomacy is not sufficiently communicated among the wider audience in Croatia (Graph 3). This perception is further confirmed by $77.1 \%$ of those who think that Croatia is not investing enough effort to use food for public diplomacy purposes.

Which public diplomacy tool Croatia is using the most?

Tourism

Sport

Culture

Gastronomy

Other

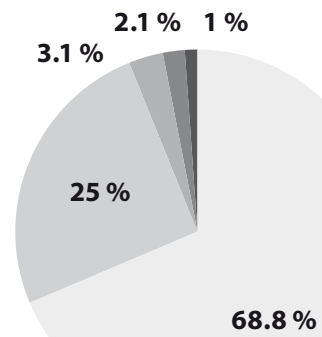

- Graph 3.

Croatia's public diplomacy tools, 


\section{CONCLUSION}

According to the preliminary research conducted among diplomats accredited to the Republic of Croatia, gastro diplomacy is very much present in their daily practice. However, an overall strategy of gastro diplomacy, coordinated by the government is still waiting to be developed in many countries. Although the survey was just an initial attempt to analyse the role of food in diplomacy, its results can serve as an indication of current practice, as well as an input to more comprehensive future research on gastro diplomacy. The part of the research conducted among students at the Faculty of Political Science of the University of Zagreb indicates that they perceive a connection between food and a country's image, as well as the potential of food in interstate relations and communicating intended or unintended messages. However, when it comes to Croatia, other public diplomacy tools, such as tourism and sports, are more visible.

Several conclusions were reached upon in the article. Firstly, the use of food was detected as a public diplomacy tool within campaigns presenting the basic elements of strategic communication focused on a very broad audience. Secondly, it is very much incorporated in every country's historical heritage. Thirdly, the food is used in interstate as well as intrastate political communication, transferring a different range of messages: from understanding and friendship to coercion or "food wars". And finally, food is used to transmit nationalism and to increase a nation's brand status. All the aforementioned elements taken together constitute a developing soft power tool.

Wine discourse is of huge importance when it interlinks with diplomatic discourse. It is no longer wine but diplomacy that is poured in the crystal glasses; it is diplomacy that excites the palatal sense in the diplomat's mouth and it is diplomacy that intoxicates the mind of the diplomat. (Constantinou, 1996: 139)

The same goes for food. However, there is a limited academic interest on gastro diplomacy, food diplomacy or culinary diplomacy within the discipline of IR. Having in mind that food is widely used in everyday diplomatic practice, that it possesses symbolic power in building and communicating national identity, and that it presents a medium for transferring different types of messages to different audiences, one can conclude that current academic research and theory lag behind the practice to a great extent.

\section{References}

>Albala, Ken (2011) The Historical Models of Food and Power in European Courts of the Nineteenth Century: An Expository Essay and Prologue, pp. 13-31 in De Vooght, Daniëlle (ed.) Royal Taste. Food, Power and Status at the European Courts after 1789. Surrey: Ashgate. DOI: 10.4324/9781315607078. >Ariel, Ari (2012) The Hummus Wars. Gastronomica: The Journal of Critical Food Studies 12 (1): 34-42. DOI: 10.1525/gfc.2012.12.1.34.

>ASEF (2016) ASEF Public Diplomacy Handbook - How to Win Hearts and Minds. Singapore: AsiaEurope Foundation. http://www.asef.org/pubs/asef-publications/4103-asef-public-diplomacyhandbook- (15.07.2017).

>Bardenstein, Carol (2010) Beyond Univocal Baklava: Deconstructing Food-as-Ethnicity and Ideology of Homeland in Diana Abu Jaber's The Language of Baklava. Journal of Arabic Literature 41 (1/2): 160-179. DOI: 10.1163/157006410x486792. 
>Barry, Dan (2009) Ambassador Hot Dog. The New York Times, 6 June 2009. http://www.nytimes. com/2009/06/07/weekinreview/07barry.html (08.08.2017).

>Barthes, Roland (2008) Toward a Psychosociology of Contemporary Food Consumption, pp. 28-35 in Counihan, Carol and van Esterik, Penny (eds) Food and Culture: A Reader. (2 $2^{\text {nd }}$ edition). New York: Routledge. >BBC (2017) Qatar Crisis: What You Need to Know. BBC News, 19 July 2017. http://www.bbc.com/ news/world-middle-east-40173757 (11.08.2017).

$>$ Bertrand, Pierre (2017) Eastern EU Countries Cry Foul over "Garbage Can" Food Quality. Euronews, 22 February 2017. http://www.euronews.com/2017/02/22/eastern-eu-countries-cry-foul-overgarbage-can-food-quality (10.08.2017). >Biščević, Hido (2013) Diplomacija za stolom (Diplomacy at the Table). Zagreb: Jutarnji list. Brillat-Savarin, Jean. A. (2009) The Physiology of Taste or Meditations on Transcendental Gastronomy. New York: Everyman's library.

$>$ Chapple-Sokol, Sam (2013) Culinary Diplomacy: Breaking Bread to Win Hearts and Minds. The Hague Journal of Diplomacy 8 (2): 161-183. DOI: 10.1163/1871191x-12341244.

>Constantinou, Costats M. (1996) On the Way to Diplomacy. Minneapolis: University of Minnesota Press.

>De Vooght, Daniëlle (2011) Culinary Networks of Power in a Nineteenth-Century Court Society: Dining with the Kings of the Belgians (1831-1909), pp. 171-191 in De Vooght, Daniëlle (ed.) Royal Taste. Food, Power and Status at the European Courts after 1789. Surrey: Asghate. DOI: $10.4324 / 9781315607078$.

$>$ Eckholm, Erik (2002) Bush to Treat China's Departing Leader to a Barbecue Summit. The New York Times, 21 October 2002. http://www.nytimes.com/2002/10/21/world/bush-to-treat-china-sdeparting-leader-to-a-barbecue-summit.html (10.08.2017).

>European Commission (2017) EU quality logos. DG Agriculture and rural development. https:// ec.europa.eu/agriculture/quality/schemes_en (09.08.2017).

>Foddy, William (1993) Constructing Questions for Interviews and Questionnaires: Theory and Practice in Social Research. Cambridge: Cambridge University Press. DOI: 10.1017/cbo9780511518201.

$>$ Georges, Robert A. (1984) You Often Eat What Others Think You Are: Food as an Index of Others' Conceptions of Who One Is. Western Folklore 43 (4): 249-256. DOI: 10.2307/1500108.

>Higman, Barry W. (2012) How Food Made History. Oxford: Wiley-Blackwell. DOI: $10.1002 / 9781444344677$.

>Hina, Jutarnji.hr (2017) Predsjednica neugodno iznenađena - 'Iznimno sam razočarana, roditeljima koji su dobili te čokoladice ćemo se ispričati i poslati hrvatske proizvode' (The President Unpleasantly Surprised - 'I am Extremely Disappointed, We Will Apologize to the Parents Who Received Those Chocolate Bars and Send Them Croatian Products'). Jutarnji list, 7 December 2016. http://www.jutarnji.hr/vijesti/hrvatska/predsjednica-neugodno-iznenadena-iznimnosam-razocarana-roditeljima-koji-su-dobili-te-cokoladice-cemo-se-ispricati-i-poslati-hrvatskeproizvode/5359815/ (09.08.2017).

>Hyun-kyung, Kang (2010) First Lady's Pet Project: Food Diplomacy. The Korea Times, 19 October 2010. http://www.koreatimes.co.kr/www/news/nation/2010/10/116_74843.html\# (09.08.2017). Ichijo, Atsuko and Ranta, Ronald (2016) Food, National Identity and Nationalism - From Everyday to Global Politics. Basingstoke: Palgrave Macmillan. DOI: 10.1057/9781137483133.

>Johnston, Chelsea Eva (2013) Beware of that Cup! The Role of Food-Tasters in Ancient Society. A thesis submitted in fulfilment of the degree of Master of Arts in Classical Studies, University of Otago. http://citeseerx.ist.psu.edu/viewdoc/download?doi=10.1.1.831.1632\&rep=rep1\&type=pdf (02.07.2017).

>Lair, Anne (2011) The Ceremony of Dining at Napoleon III's Court Between 1852 and 1870, pp. 143171 in De Vooght, Daniëlle (ed.) Royal Taste. Food, Power and Status at the European Courts after 1789. Surrey: Asghate. DOI: 10.4324/9781315607078.

>Lamza Posavec, Vesna (2011) Kvantitativne metode istraživanja: anketa i analiza sadržaja. Zagreb: Hrvatski studiji. 
$>$ Melissen, Jan (2005) The New Public Diplomacy: Between Theory and Practice, pp. 3-27 in Melissen, Jan (ed.) The New Public Diplomacy - Soft Power in International Relations. Basingstoke: Palgrave Macmillan. DOI: 10.1057/9780230554931_1. $>$ Mikolić, Mario (2002) Diplomatski i poslovni protokol (Diplomatic and Business Protocol). Zagreb: Barbat.

$>$ Milner, N. P. (translator) (1996) Vegetius: Epitome of Military Science (2 ${ }^{\text {nd }}$ edition). Liverpool: Liverpool University Press. DOI: 10.3828/978-0-85323-910-9.

>Nick, Stanko (1997) Diplomacija: metode i tehnike (Diplomacy: Methods and Techniques).

Zagreb: Barbat.

$>$ Nye, Joseph S., Jr. (2008) Public Diplomacy and Soft Power. The Annals of the American Academy of Political and Social Science 616 (1): 94-109. DOI: 10.1177/0002716207311699.

$>$ Nye, Joseph S., Jr. (2004) Soft Power: Means to Success in World Politics. NY: Public Affairs.

$>$ Nye, Joseph S., Jr. (1990) Soft Power. Foreign Policy (80): 153-171. DOI: 10.2307/1148580.

$>$ Pavlić, Vedran (2016) Slovenian Diplomats Angry about Croatian Holiday Presents. Total Croatia News, 20 December 2016. http://www.total-croatia-news.com/politics/15351-slovenian-diplomatsangry-about-croatian-holiday-presents (10.08.2017).

$>$ Qian Ng, Clarrie Si (2015) Culinary Diplomacy and Nationalism. Japan and Thailand. http://www. academia.edu/11476784/Culinary_Diplomacy_and_Nationalism_Japan-and_Thailand (15.07.2017). $>$ Raviv, Yael (2003) Falafel: A National Icon. Gastronomica 3 (3): 20-25. DOI: 10.1525/gfc.2003.3.3.20. Reynolds, Christian John (2010) Tipping the Scales: A New Understanding of Food's Power in the Political Sphere. International Journal of Interdisciplinary Social Sciences 5 (7): 295-304. DOI: 10.18848/1833-1882/cgp/v05i07/51783.

$>$ Riordan, Shaun (2017) Stop Inventing "New Diplomacies". CPD Blog. University of South Carolina, Center on Public Diplomacy. https://uscpublicdiplomacy.org/blog/stop-inventing-newdiplomacies (21.07.2017).

$>$ Rockower, Paul S. (2012) Recipes for Gastrodiplomacy. Place Branding and Public Diplomacy 8 (3): 235-246. DOI: 10.1057/pb.2012.17.

>Sagioglou, Christina and Greitemeyer, Tobias (2014) Bitter taste causes hostility. Personality and Social Psychology Bulletin 40 (12): 1589-1597. DOI: 10.1177/0146167214552792.

$>$ Sanger, David E. (2001) The Bush-Putin Summit: The Ranch; Before and After Bush and Putin's Banter, No Agreement on Missile Defense. The New York Times, 16 November 2001. http://www. nytimes.com/2001/11/16/world/bush-putin-summit-ranch-before-after-bush-putin-s-banter-noagreement-missile.html (01.08.2017).

$>$ Sang-Hun, Choe (2008) Kimchi Goes to Space, Along with First Korean Astronaut. The New York Times, 22 February 2008. http://www.nytimes.com/2008/02/22/world/asia/22iht-kimchi.1.10302283. html (09.08.2017).

>Sciolino, Elaine (2008) Time to Save the Croissants. The New York Times, 23 September 2008. http:// www.nytimes.com/2008/09/24/dining/24heritage.html (07.08.2017).

>Šišović, D. (2017) Priča je konačno završena - teran je napokon opet naš! (The Story is Finally Over - Teran is Finally Ours Again! Glas Istre, 19 July 2017. https://www.glasistre.hr/791e101a-77cb-4c75a036-ccadc258d900 (09.08.2017).

>Snow, Nancy and Taylor, Phillip M. (eds) (2009) Routledge Handbook of Public Diplomacy. New York and London: Routledge. DOI: 10.4324/9780203891520.

>Spence, Charles (2016) Gastrodiplomacy: Assessing the Role of Food in Decision Making. Flavour 5 (4): 1-16. DOI: 10.1186/s13411-016-0050-8.

$>$ Standage, Tom (2009) An Edible History of Humanity. New York: Walker Publishing Company. Steel, Carolyn (2008) Hungry City: How Food Shapes Our Lives. London: Chatto \& Windus.

The Economist (2002) Thailand's Gastro-Diplomacy. The Economist, 21 February 2002. http://www. economist.com/node/999687 (01.08.2017).

>UNESCO (2013) Mediterranean Diet. https://ich.unesco.org/en/RL/mediterranean-diet-00884 (12.08.2017). 
>USC CPD (2015) Eight Great Gastrodiplomacy Nations. University of Southern California, Center for Public Democracy. https://uscpublicdiplomacy.org/story/eight-great-gastrodiplomacy-nations (21.07.2017).

>Watfa, Rhéa and Pallister, Stuart (2017) The Power of Food Diplomacy and Hospitality, in the Service of a Nation. HN hospitalitynet, 1 March 2017. https://www.hospitalitynet.org/ opinion/4081239.html (20.07.2017).

$>$ Weiss Adamson, Melitta and Segan, Francine (2008) (eds) Entertaining from Ancient Rome to the Super Bowl: An Encyclopedia. London: Greenwood Press.

$>$ WNYC.org (2014) Khrushchev Eats a Hot Dog and Why History is Sometimes Comedy? http://www. wnyc.org/story/khrushchev-tours-america-and-why-history-sometimes-comedy/ (09.08.2017).

>Zaru, Deena (2016) Feathers Fly over Donald Trump Eating Fried Chicken with a Fork. CNN politics, 3 August 2016. http://edition.cnn.com/2016/08/02/politics/donald-trump-eats-kfc-knife-fork/index. html (03.08.2017).

>Zhang, Juyan (2015) The Foods of the Worlds: Mapping and Comparing Contemporary Gastrodiplomacy Campaigns. International Journal of Communication 9: 568-591. http://ijoc.org/ index.php/ijoc/article/view/2847/1316 (12.08.2017). 


\section{ULOGA HRANE U DIPLOMACIJI: KOMUNICIRANJE | "OSVAJANJE SRCA I DUŠE" HRANOM}

\section{Đana Luša :: Ružica Jakešević}

SAŽETAK Hrana kao esencijalni sastojak ljudske egzistencije oduvijek je igrala važnu ulogu u međudržavnim odnosima i diplomatskoj praksi te je bila korištena kao medij kroz koji se projicira utjecaj, komuniciraju kultura i identitet te poruke koje izražavaju prijateljstvo ili neprijateljstvo. Uloga hrane sve je istaknutija u javnodiplomatskoj praksi različitih država, dok su akademska razmatranja gastrodiplomacije, kulinarske diplomacije ili diplomacije hranom do sada bila ograničena unutar discipline međunarodnih odnosa. Cilj je članka predstaviti različite aspekte ovog novog interdisciplinarnog polja istraživanja široj akademskoj zajednici, polazeći od hipoteze da hrana u sve većoj mjeri postaje prepoznata kao službeno sredstvo meke moći i javne diplomacije. U članku se prezentiraju rezultati inicijalnog istraživanja provedenog među diplomatima akreditiranima u Republici Hrvatskoj te anketnog istraživanja provedenog među studentima Fakulteta političkih znanosti Sveučilišta u Zagrebu.

KLJUČNE RIJEČI

JAVNA DIPLOMACIJA, DIPLOMACIJA HRANOM, GASTRODIPLOMACIJA, KULINARSKA DIPLOMACIJA, MEKA MOĆ, KOMUNIKACIJA

Bilješka o autoricama

Đana Luša :: Sveučilište u Zagrebu, Fakultet političkih znanosti, Zagreb :: dana.lusa@fpzg.hr Ružica Jakešević :: Sveučilište u Zagrebu, Fakultet političkih znanosti, Zagreb :: ruzica.jakesevic@fpzg.hr 